University of Nebraska - Lincoln

DigitalCommons@University of Nebraska - Lincoln

Publications, Agencies and Staff of the U.S.

Department of Commerce

U.S. Department of Commerce

10-1999

\title{
Gray Whales (Eschrichtius robustus) Off Sakhalin Island, Russia: Seasonal And Annual Patterns Of Occurrence
}

\author{
David Weller \\ Texas A\&M University \\ Bernd Wursig \\ Texas A\&M University \\ Amanda Bradford \\ Texas A\&M University
}

Alexander Burdin

Kamchatka Institute of Ecology and Nature Management, Kamchatka, 683000, Russia

Sergey Blokhin

Pacific Institute of Fisheries and Oceanography, Vladivostok, 690600, Russia

See next page for additional authors

Follow this and additional works at: https://digitalcommons.unl.edu/usdeptcommercepub

Part of the Environmental Sciences Commons

Weller, David; Wursig, Bernd; Bradford, Amanda; Burdin, Alexander; Blokhin, Sergey; Minakuchi, Hiroya; and Brownell, Robert L. Jr., "Gray Whales (Eschrichtius robustus) Off Sakhalin Island, Russia: Seasonal And Annual Patterns Of Occurrence" (1999). Publications, Agencies and Staff of the U.S. Department of Commerce. 83.

https://digitalcommons.unl.edu/usdeptcommercepub/83

This Article is brought to you for free and open access by the U.S. Department of Commerce at DigitalCommons@University of Nebraska - Lincoln. It has been accepted for inclusion in Publications, Agencies and Staff of the U.S. Department of Commerce by an authorized administrator of DigitalCommons@University of Nebraska - Lincoln. 


\section{Authors}

David Weller, Bernd Wursig, Amanda Bradford, Alexander Burdin, Sergey Blokhin, Hiroya Minakuchi, and Robert L. Brownell Jr. 


\title{
GRAY WHALES (ESCHRICHTIUS ROBUSTUS) OFF SAKHALIN ISLAND, RUSSIA: SEASONAL AND ANNUAL PATTERNS OF OCCURRENCE ${ }^{1}$
}

\author{
DAVID W. WeLLER ${ }^{2}$ \\ BERND WÜRSIG \\ Amanda L. Bradford ${ }^{2}$ \\ Marine Mammal Research Program \\ Texas A\&M University \\ 4700 Avenue U, Building 303, \\ Galveston, TX 77551, U.S.A. \\ E-mail: dweller@sgilj.ucsd.edu \\ Alexander M. Burdin \\ Kamchatka Institute of Ecology and Nature Management \\ Kamchatka, 683000, Russia \\ Sergey A. Blokhin \\ Pacific Institute of Fisheries and Oceanography \\ Vladivostok, 690600, Russia \\ Hiroya Minakuchi \\ CETUS, \\ Yokohama 245, Japan \\ Robert L. Brownell, JR. \\ Southwest Fisheries Science Center, \\ National Marine Fisheries Service, \\ P. O. Box 271, \\ La Jolla, California 92038, U.S.A.
}

\begin{abstract}
The annual return, seasonal occurrence, and site fidelity of Korean-Okhotsk or western gray whales on their feeding grounds off northeastern Sakhalin Island, Russia, were assessed by boat-based photo-identification studies in 1994-1998. A total of 262 pods were observed, ranging in size from 1 to 9 whales with an overall mean of 2.0 . Sixty-nine whales were individually iden-

${ }^{1}$ We dedicate this paper to Ken Norris, a pioneer and leader of research on the behavioral ecology and conservation-related status of gray whales.

${ }^{2}$ Present address: Southwest Fisheries Science Center, National Marine Fisheries Service, P.O. Box 271, La Jolla, CA 92038, U.S.A.
\end{abstract}


tified, and a majority of all whales $(71.0 \%)$ were observed in multiple years. Annual sighting frequencies ranged from 1 to $18 \mathrm{~d}$, with a mean of $5.4 \mathrm{~d}$. The percentage of whales reidentified from previous years showed a continuous annual increase, reaching $87.0 \%$ by the end of the study. Time between first and last sighting of identified individuals within a given year was $1-85 \mathrm{~d}$, with an overall mean of $40.6 \mathrm{~d}$. Annual calf proportions ranged from $4.3 \%$ (1997) to $13.2 \%$ (1998), and mother-calf separations generally occurred between July and September. The seasonal site fidelity and annual return of whales to this part of the Okhotsk Sea emphasize its importance as a primary feeding ground for this endangered population.

Key words: western gray whale, Eschricbtius robustus, Okhotsk Sea, Russia, photo-identification, occurrence patterns, site fidelity.

Gray whales are known to occur as two separate populations along the eastern and western margins of the North Pacific (Rice and Wolman 1971). While both populations were hunted to near extinction, only the eastern North Pacific or California-Chukchi gray whale has returned to pre-exploitation population levels (Reilly 1992, Clapham et al. 1999). The western North Pacific or Korean-Okhotsk gray whale was thought to be extinct as recently as the early 1970s (Bowen 1974) but is known to survive today as a remnant population (Brownell and Chun 1977, Blokhin et al. 1985, Berzin et al. 1990). This western population is presently considered one of the most endangered and little-known large-whale populations in the world (Berzin et al. 1995, Brownell et al. 1997, Brownell 1999, Clapham et al. 1999). The current population size has been reported as 100-250 whales (Vladimirov 1994; Blokhin 1996; Berzin, in press); however, no reliable quantitative data have existed to confirm these assessments.

Basic information regarding the life history and biology of western gray whales is sparse, and only recently has this population come under concerted study (Brownell et al. 1997, Würsig et al. 1999). Historic sighting data and whaling records suggest that summer feeding grounds are in the Okhotsk Sea and that the whales migrate to presently unknown breeding grounds suspected to be along the coast of southern China (Henderson 1972, 1984, 1990; Yablokov and Bogoslovskaya 1984; Kato and Kasuya, in press). Sighting records from aerial and vessel surveys in the Okhotsk Sea between 1979 and 1989 indicated that feeding gray whales aggregated predominately along the shallow-water shelf of northeastern Sakhalin Island, Russia, and were particularly abundant off the southern portion of a coastal lagoon called Zaliv Pil'tun (Blokhin et al. 1985; Berzin et al. 1988, 1990, 1991, in press; Blokhin 1996).

Concerns regarding the status of western gray whales have intensified as a result of continued low-level human-related mortality south of the Okhotsk Sea (Brownell 1999) and the onset of large-scale U.S.-Russian oil and gas development programs near the only known gray whale feeding ground within Okhotsk waters (Brownell et al. 1997, Würsig et al. 1999). In response to these concerns, a joint research project under the U.S.-Russian Environmental Agreement (Marine Mammal Project) was initiated in 1995 to examine the conservation status, occurrence, distribution, behavior, and potential human- 
related disturbance of gray whales off the northeastern coast of Sakhalin Island. Principal research components of this project included aerial surveys, shorebased behavioral observations, theodolite tracking, acoustic monitoring, biopsy sampling, and photo-identification (Würsig et al. 1998, 1999). Findings presented here represent information from photo-identification studies between 1994 and 1998, and summarize patterns of seasonal and annual occurence of western gray whales on their feeding grounds in the Okhotsk Sea.

\section{Methods}

\section{Study Area}

Zaliv Pil'tun (referred to here as Piltun Lagoon) is located on the northeastern shore of Sakhalin Island, Russia (Fig. 1). The lagoon is approximately $80 \mathrm{~km}$ long and $15 \mathrm{~km}$ across at its widest point. A single entrance connecting the inner lagoon with waters of the Okhotsk Sea occurs at $52^{\circ} 50^{\prime} \mathrm{N}, 143^{\circ} 20^{\prime} \mathrm{E}$. This channel, approximately $18 \mathrm{~km}$ north of the lagoon's southern boundary, served as the base from which studies reported here were conducted. The nearshore marine environment of the study site is predominately sand substrate, characterized by a gradually sloping and broad continental shelf. Water depths within $5 \mathrm{~km}$ of shore are almost uniformly less than $20 \mathrm{~m}$ (Fig. 1). Sea-surface temperature and salinity, as measured from our research vessel during 1997-1998, were $4^{\circ}-15^{\circ} \mathrm{C}$ and $28 \%$ - 34\%o, respectively. Periods free of sea ice occur mainly between May and December; however, significant interannual variability exists.

\section{Datasets}

Data presented here were collected during four years: 1994, 1995, 1997, and 1998. Gray whale photographs from 1994 were taken 7-12 September during the filming of a wildlife documentary by one of the authors (HM). No information other than sighting locations is available for the 1994 sampling period. In 1995 a pilot study to determine the feasibility of conducting systematic research in the Piltun area was completed 14-20 August (Brownell et al. 1997). Intensive follow-up work in July-September 1997 and 1998 contributed substantially to the findings presented here. Because of the opportunistic nature of the 1994 season and the brevity of the 1995 season, many analyses detailed here were restricted to only the more comprehensive 1997 and 1998 datasets. However, the 1994 and 1995 samples provided particularly valuable information regarding interannual sightings and general site fidelity patterns for known individuals. The sampling periods used for each respective analysis are defined. For example, the term "1995-1998" is used to define analyses that incorporated data from 1995, 1997, and 1998.

\section{Photo-Identification Surveys}

Boat-based photo-identification surveys following nearly identical research protocols were conducted during each of the 1995-1998 field seasons. These 


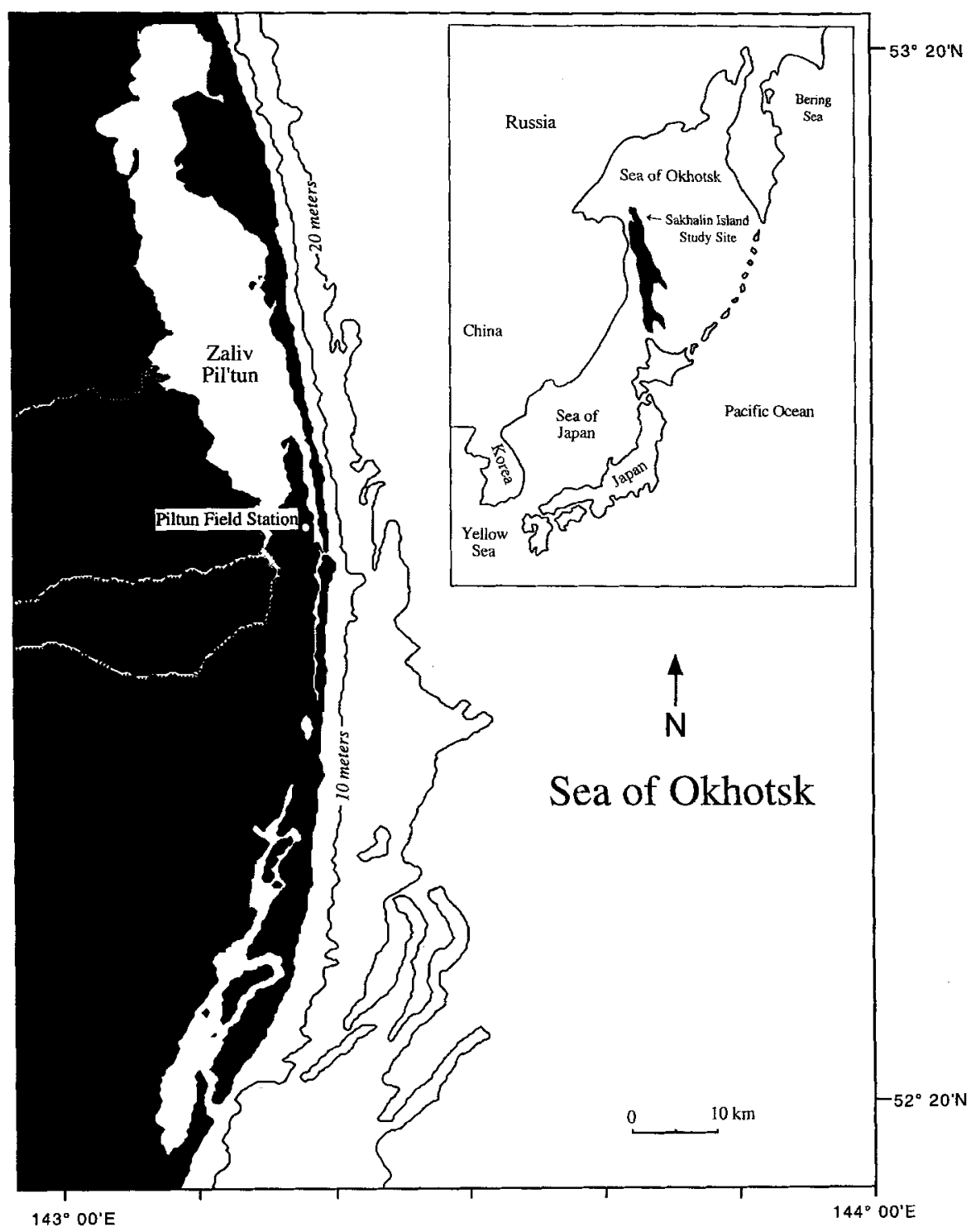

Figure 1. Map of Piltun study area. Inset shows relative location of Sakhalin Island in Sea of Okhotsk.

surveys followed no predetermined systematic vessel track and were conducted in such a manner as to maximize encountering and photographically identifying as many whales as possible. Photographic data from 1994-1995 targeted right-side dorsal flank markings as the primary body aspect for identification purposes (Brownell et al. 1997). For the sake of intra- and interannual reliability, this methodological approach was continued in 1997-1998. Photographs from 1997-1998 were taken with a Nikon F5 35-mm camera equipped 
with a 100-300-mm zoom telephoto lens, 8 frames per sec motordrive, and databack. Video footage was recorded with a Sony DCR-VX1000 digital camera. Two 35-mm film types were used: Kodachrome 200 ISO color and T-Max 400 ISO black and white.

Photographic surveys involved slow travel in a 4.5-m outboard-powered inflatable boat. The research team consisted of a boat driver, data recorder, digital video camera operator, and $35-\mathrm{mm}$ camera photographer. Systematic search from the survey vessel was maintained until a whale sighting was made. Upon initial sighting of a pod, the survey vessel slowed to idle speed and maneuvered to a vantage point approximately $50 \mathrm{~m}$ from the whale(s). From this position observations on pod location (as determined by Global Positioning System), time, behavior, and number of whales were recorded.

The research vessel was then maneuvered within 5-15 m of the pod and individual whales were photographed. During the 1997-1998 photographic efforts, running commentaries regarding film-frame and video-counter number as related to particular whales were recorded on data sheets. Measures of water depth, location, and environmental conditions were documented on average every 3-5 min throughout the entire photographic session. In all cases attempts were made to simultaneously photograph and videotape the right dorsal flank of each whale, followed by the left dorsal flank, and dorsal and ventral aspects of the flukes. Written observations and video footage collected at the time of each photographic session were used to link inter- and intraindividual body aspects whenever possible.

Contact with whale pods was maintained until all individuals encountered had been photographed. The boat then motored away from the pod, where initial estimates of pod size and composition were revised if necessary and all film and written records reviewed for completeness. These procedures were repeated as the research vessel resumed travel and additional whale pods were encountered.

A pod was defined as either a solitary individual, or two or more whales observed in close spatial proximity (within several body lengths of each other) and swimming in close association and generally coordinating their diving or direction of movement (see Clapham 1993). Pod size estimates were based on field observations and represented the product of a consensus among observers on the survey vessel. The term "calf" is used here to refer to young of the year. In all cases calves were initially identified by their small body size (about one-third that of a mature adult) and constant association with a particular adult whale. Calves documented to disaffiliate from their mothers at some point during the field season were termed "newly independent calves."

\section{Photo-Identification Analysis}

Photographic identification has proved to be a valuable research tool for gray whale studies (Darling 1984, Swartz 1986, Jones 1990) and served as the primary method for collecting the data presented here. As is true for the eastern population, western gray whales are easily identified by pigmentation 

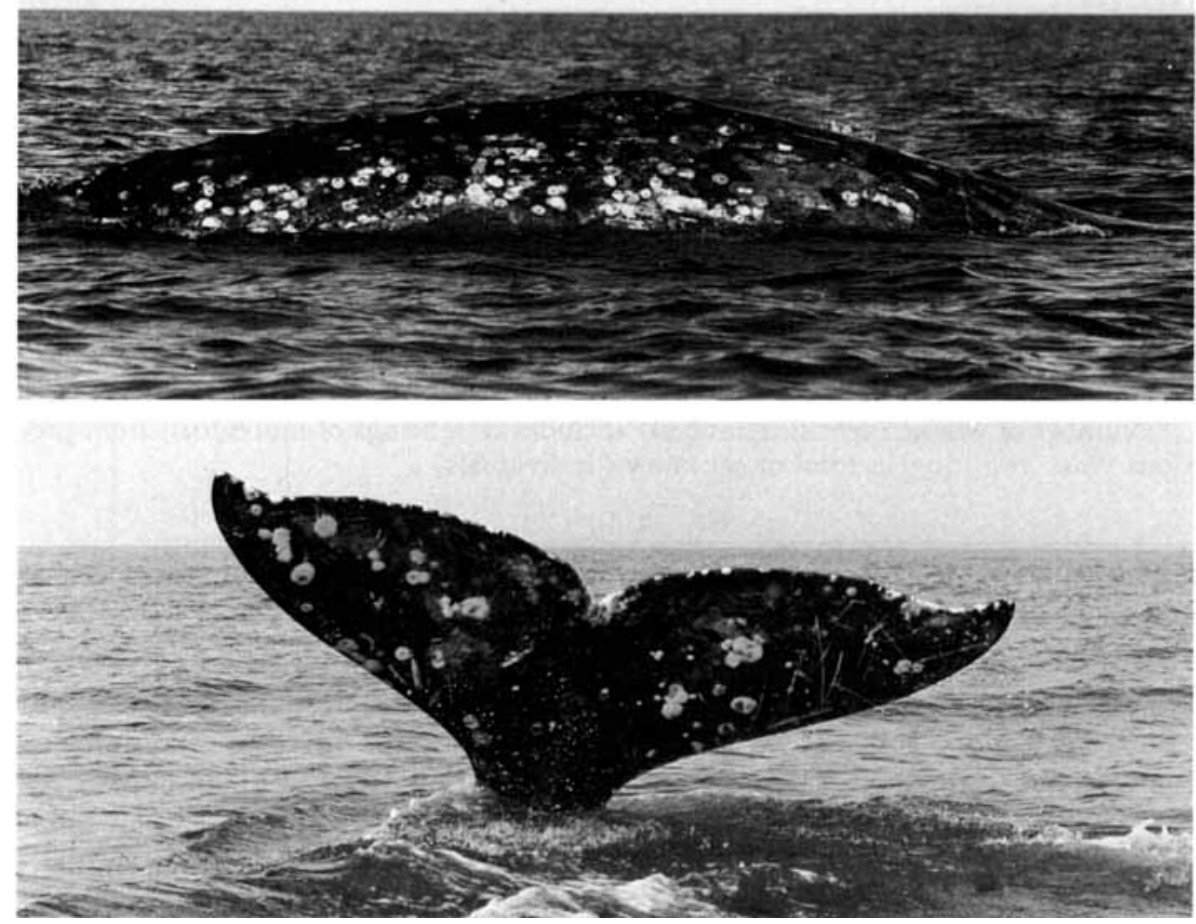

Figure 2. Examples of coloration patterns used for individual recognition of gray whales.

patterns and scars (Fig. 2). Patches of barnacles (Cryptolepas rbachianceti) and cyamids (Cyamus scammoni and/or Cyamus ceti) and occasionally-apparent killer whale (Orcinus orca) tooth rakes were not used for long-term recognition.

Images of individual gray whales consisted of various aspects of the body, including the head, back, dorsal flanks, and flukes. To prevent cataloging different aspects of the same whale as more than one individual, the right flank was always used as the basis for initial identification. A whale was not given a subject identification number unless its right dorsal flank was photographed at some point during the field season. Additional aspects of the body were used as identification aids, only if they were first matched with the respective right flank.

Photographic matching was done by comparing new photographs to a catalog of previously identified whales. Once a prospective resighting was located, the current photograph was repeatedly compared to previous images and was required to match before being confirmed as a re-identification of a known individual. If a new photograph could not be matched after comparison to all other cataloged individuals, the whale was considered new and given the next available subject identification number. All images were processed and cata- 
Table 1. Annual survey effort, number of pods encountered, and whales identified. Time in decimal hours.

\begin{tabular}{lcccccc}
\hline \hline Year & $\begin{array}{c}\text { Sampling } \\
\text { period }\end{array}$ & $\begin{array}{c}\text { Number } \\
\text { of surveys }\end{array}$ & $\begin{array}{c}\text { Hours } \\
\text { of obser- } \\
\text { vation }\end{array}$ & $\begin{array}{c}\text { Rolls } \\
\text { of film } \\
\text { used }\end{array}$ & $\begin{array}{c}\text { Pods } \\
\text { encoun- } \\
\text { tered }\end{array}$ & $\begin{array}{c}\text { Whales } \\
\text { identified }\end{array}$ \\
\hline $1994^{\mathrm{a}}$ & $09 / 07-09 / 12$ & - & - & - & - & 9 \\
1995 & $08 / 15-08 / 19$ & 5 & 10.1 & 15 & 23 & 26 \\
1997 & $07 / 09-09 / 08$ & 22 & 33.4 & 72 & 114 & 46 \\
1998 & $07 / 06-09 / 29$ & 35 & 50.5 & 91 & 125 & 53 \\
Overall & & 62 & 94.0 & 178 & 262 & $69^{\mathrm{b}}$ \\
\hline
\end{tabular}

Opportunistic photographs collected during several days in mid-September, 1994. Information other than the number of whales identified not recorded.

${ }^{b}$ Number of whales identified annually includes resightings of individuals from previous years, resulting in total of 69 known individuals.

loged by a single expert operator, with confirmation of both re-identifications and new whales by additional personnel.

Digital video footage was collected simultaneously with still photography during a majority of the photo-identification surveys conducted in 1997 and 1998. Each video session was reviewed frame by frame to verify and enhance the already established 35-mm photographic catalog. If the videographer recorded a previously unphotographed whale or an additional aspect of an identified whale, then a still print was made. Video images of whales not accounted for by 35-mm photographs were systematically matched following the protocol described above. The use of digital video proved especially valuable in increasing sighting frequencies and providing additional aspects of already identified whales.

\section{Results}

\section{Observation Effort}

Sixty-two photo-identification surveys totaling $94 \mathrm{~h}$ spent in direct observation of whale pods were completed in 1995-1998 (Table 1). The greatest amount of observation occurred during 1998 (50.5 h), and the lowest during the pilot study in $1995(10.1 \mathrm{~h})$. A total of 511 whales in 262 pods were encountered, and 178 rolls of film and nine hours of digital videotape were used for individual identification.

\section{Rate of Discovery}

The number of whales identified increased during each of the four annual sampling periods (Fig. 3). Nine whales were identified in 1994 and 21 additional whales (including two calves) in 1995. The number of known individuals increased to 56 (including two calves) in 1997, representing an increase of 26 new whales. With the addition of 13 new whales (including seven calves) 


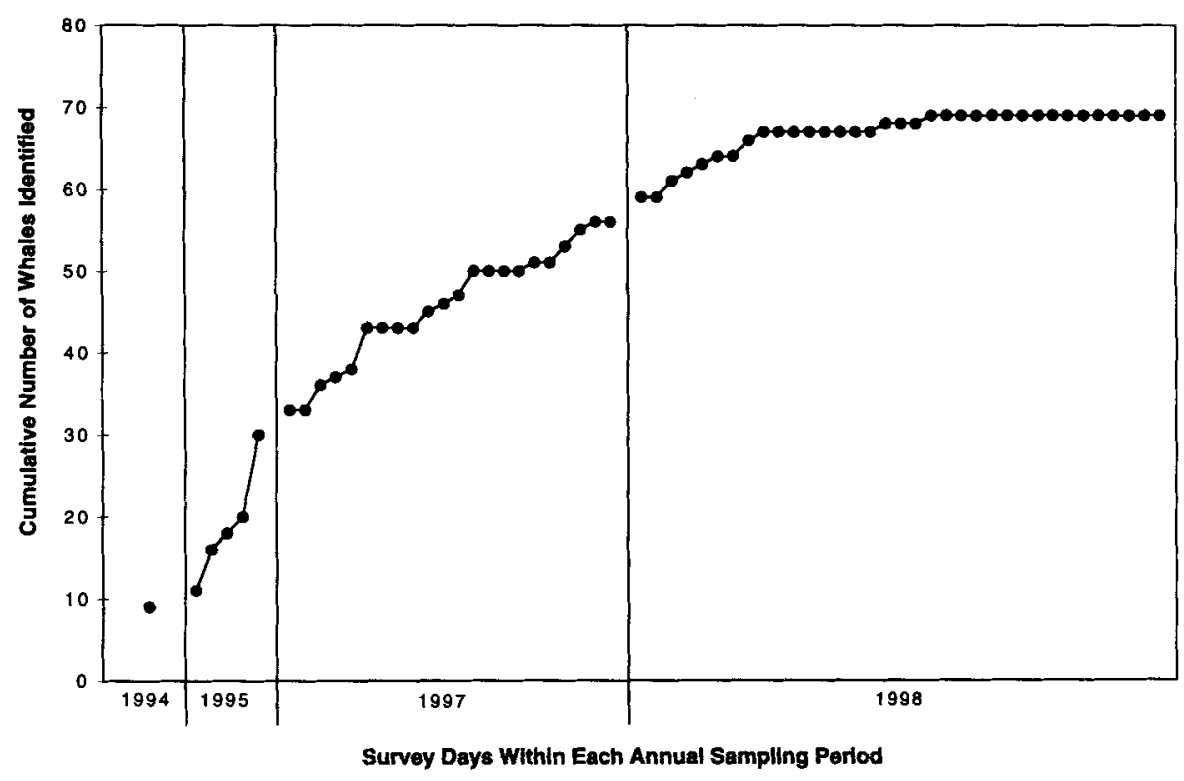

Figure 3. Rate of discovery curve for whales identified 1994-1998. Each solid circle represents one photo-identification survey.

in 1998 , a total of 69 individual whales (including 11 calves) were identified during the study. The continuous increase in the number of new identifications through 1997 and into 1998 indicated that at least some previously unidentified whales were present in the study area on a yearly basis. However, the rate at which previously unidentified whales were sighted reached an apparent asymptote by 24 July 1998 , with only two new individuals identified in the final 26 surveys of the study.

\section{Occurrence and Resighting Patterns}

Sighting frequencies for the 66 whales identified in 1997-1998 are plotted in Figure 4. As some whales were sighted more than once per day, the following analyses were constrained to include only one sighting per day. The number of sightings per individual ranged from 1 to 8 in 1997 and 1 to 18 in 1998 , with an overall mean of 5.4 sightings per yr (Fig. 4). The period between the first and last sighting of an individual whale in either 1997 or 1998 ranged from 1 to $85 \mathrm{~d}$. This measure was calculated only for whales photographed on two or more days in a year and does not assume that the individual was absent from or present in the study area for the period between sightings (see Seipt et al. 1990, Clapham et al. 1993). The mean period between first and last sighting for whales observed in 1997 and 1998 was $35.9 \mathrm{~d} \pm \mathrm{SD}$ $17.74(n=34)$ and $45.2 \mathrm{~d} \pm \mathrm{SD} 24.38(n=35)$, respectively, with an overall combined mean of $40.6 \mathrm{~d} \pm \operatorname{SD} 21.73(n=69)$.

Monthly occurrence patterns, a partial indicator of site fidelity, were ex- 


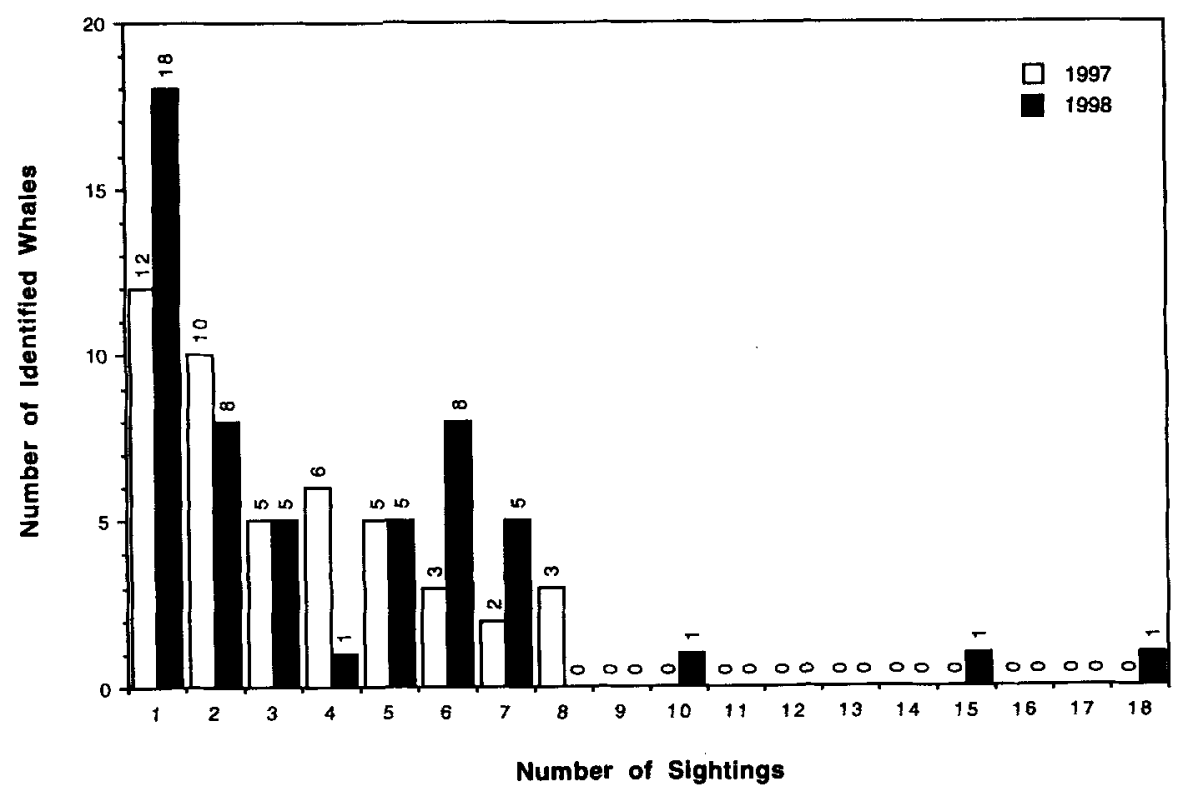

Figure 4. Sighting frequencies for whales identified 1997-1998.

1997

\begin{tabular}{|c|c|c|c|c|}
\hline July & August & September & Number of Whales & Percentage \\
\hline & & 5 & $10.9 \%$ \\
\hline & & 4 & $8.7 \%$ \\
\hline & & 6 & $13.0 \%$ \\
\hline & & 8 & $17.4 \%$ \\
\hline & & 7 & $15.2 \%$ \\
\hline & & 3 & $6.5 \%$ \\
\hline & & 13 & $28.3 \%$ \\
\hline & & 46 & $100.0 \%$ \\
\hline
\end{tabular}

1998

\begin{tabular}{|c|c|c|c|c|}
\hline July & August & September & Number of Whales & Percentage \\
\hline & & & 13 & $24.5 \%$ \\
\hline & & & 6 & $11.3 \%$ \\
\hline & & & 5 & $9.4 \%$ \\
\hline & & & 9 & $17.0 \%$ \\
\hline & & 3 & $5.7 \%$ \\
\hline & & & 1 & $1.9 \%$ \\
\hline & & & 16 & $30.2 \%$ \\
\hline & & Total & 53 & $100.0 \%$ \\
\hline
\end{tabular}

Figure 5. Cumulative percentage and number of individuals sighted in each possible monthly combination of 1997 and 1998. 
Table 2. Annual return rates of identified whales. Numbers in year columns represent percentage and number of whales identified in given year that were resighted in additional years. For example, $44.4 \%$ of whales first identified in 1994 were sighted in all four years of study.

\begin{tabular}{lccccc}
\hline $\begin{array}{l}\text { Year first } \\
\text { identified }\end{array}$ & $\begin{array}{c}\text { Number of } \\
\text { whales } \\
\text { identified }\end{array}$ & 1 year & 2 years & 3 years & 4 years \\
\hline 1994 & 9 & - & $\begin{array}{c}44.4 \% \\
(n=4)\end{array}$ & $\begin{array}{c}11.1 \% \\
(n=1)\end{array}$ & $\begin{array}{c}44.4 \% \\
(n=4)\end{array}$ \\
1995 & 21 & $\begin{array}{c}14.3 \% \\
(n=3) \\
34.6 \% \\
1997\end{array}$ & $\begin{array}{c}33.3 \% \\
(n=7) \\
65.4 \% \\
(n=9)\end{array}$ & $\begin{array}{c}52.4 \% \\
(n=11)\end{array}$ & - \\
\hline
\end{tabular}

amined for the 1997 and 1998 datasets. The number of individuals occurring in each of seven possible monthly combinations is shown in Figure 5. In 1997, $67.4 \%(n=31)$ of the individuals identified were seen in two or three months. In $1998,54.7 \%(n=29)$ of the whales identified were sighted in two or three months (Fig. 5). It is likely, however, that the limited number of surveys $(n=4)$ conducted in the third month of 1997 may have contributed to an underestimate of actual monthly occurrence patterns for that year.

Seasonal sighting patterns were also investigated for intra- and inter-annual consistency (Fig. 5). A majority of the whales sighted in two months during either 1997 or 1998 were sighted in consecutive months (i.e., July-August or August-September) as opposed to an interrupted (i.e., July-September) monthly sighting pattern. Interannual repetition of individual monthly sighting patterns was not apparent. Of 15 whales sighted in only a single month of $1997,26.7 \%(n=4)$ showed a similar pattern in 1998. None of the whales sighted in 1997 and 1998 had the same two-month occurrence pattern, and of the 13 whales sighted in all three months of $1997,53.8 \%(n=7)$ were also sighted in all three months of 1998.

Annual sighting frequencies for the 56 whales identified between 1994 and 1997 ranged from one to four years (Table 2 and Fig. 6). Seventy-one percent of all whales identified (excluding seven 1998 calves) were sighted in multiple years. The longest interval between sightings was documented for whales 050 and 068, which were first identified in 1994 and not seen again until 1998 (Fig. 6). Interannual resighting patterns are detailed in Table 3. In 1995, 26 individuals (including two calves) were identified; of the 24 non-calves, $20.8 \%$ $(n=5)$ were first identified in 1994 . This resighting trend, albeit greatly amplified, was also apparent for the 1997 sample. During this effort, 46 individuals (including two calves) were identified; of the 44 non-calves, $45.5 \%$ $(n=20)$ were previously identified in either 1994 or 1995 . These interannual sighting patterns, based on 1994 and 1995 data, are likely to underrepresent actual return rates due to the limited number of sampling days in those years (see Table 1). In 1998, 53 individuals (including seven calves) were identified; of the 46 non-calves, $87.0 \%(n=40)$ were already known from previous years, 


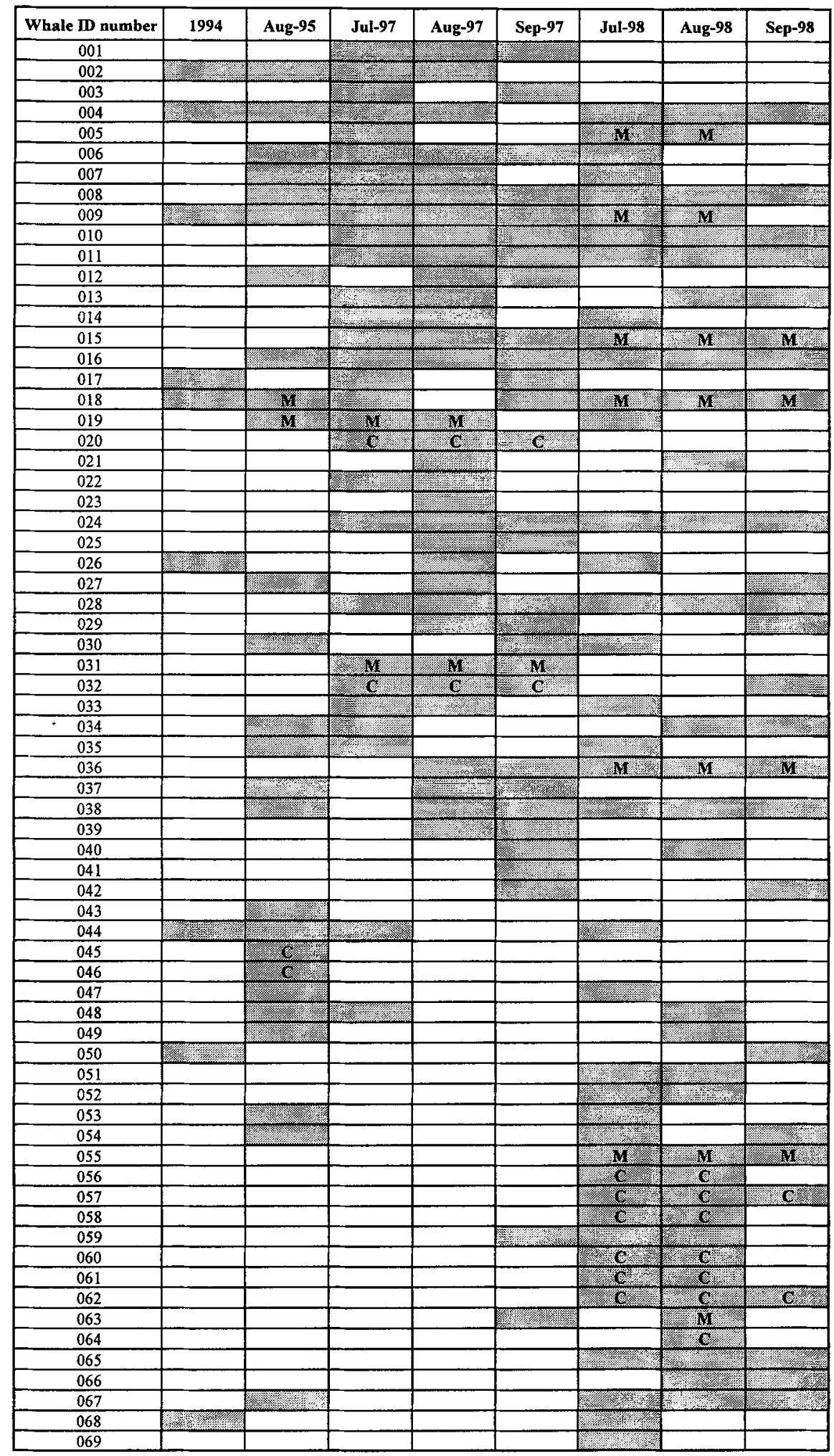


Table 3. Annual sighting trends and resighting percentages of photo-identified whales.

\begin{tabular}{lccccc}
\hline Year & $\begin{array}{c}\text { Number of } \\
\text { whales } \\
\text { identified }\end{array}$ & $\begin{array}{c}\text { Number of } \\
\text { calves }\end{array}$ & $\begin{array}{c}\text { Number of } \\
\text { new whales } \\
\text { identified }\end{array}$ & $\begin{array}{c}\text { Percentage of } \\
\text { non-calves } \\
\text { identified from } \\
\text { previous years }\end{array}$ & $\begin{array}{c}\text { Number of } \\
\text { whales } \\
\text { seen only } \\
\text { in that year }\end{array}$ \\
\hline 1994 & 9 & - & 9 & N/A & 0 \\
1995 & 26 & 2 & 21 & $20.8 \%(n=5)$ & 3 \\
1997 & 46 & 2 & 26 & $45.5 \%(n=20)$ & 9 \\
1998 & 53 & 7 & 13 & $87.0 \%(n=40)$ & $13^{\text {a }}$ \\
\hline
\end{tabular}

${ }^{a}$ Seven of these 13 whales were "young of the year" calves, and therefore could not have been sighted in any other sampling period.

including one whale recorded as a calf in 1997. Therefore, during the 1998 field effort only six new non-calf individuals were identified, and all but two of the 13 new whales for this year were photographed in the first month of the three-month field effort.

Based on 1998 data alone, the minimum number of gray whales utilizing the study area was 53 , consisting of 46 non-calves and seven calves. However, if each whale identified between 1994 and 1998 is assumed to be living, this number can be increased to 69 whales, including a minimum of 11 calves born between 1995 and 1998 .

\section{Pod Sizes}

A total of 262 whale pods were observed between 1995 and 1998 . Pod sizes ranged from 1 to 9 whales, with an overall mean of $2.0 \pm$ SD $1.18(n$ $=262$ ), a median of 2 , and a mode of 1 (Table 4, Fig. 7). Pods containing a single whale were the most frequently encountered, and accounted for $43.1 \%$ $(n=113)$ of all sightings. Overall, pods of 4 or fewer accounted for $97.7 \%$ $(n=256)$ of all sightings.

The largest pod sizes were documented in $1995(\bar{x}=2.3 \pm \operatorname{SD} 1.18, n=$ 23) and the smallest in $1997(\bar{x}=1.8 \pm \mathrm{SD} 1.33, n=114)$ (Table 4). Between 1997 and 1998 overall pod sizes were larger in July $(\bar{x}=2.1 \pm \mathrm{SD}$

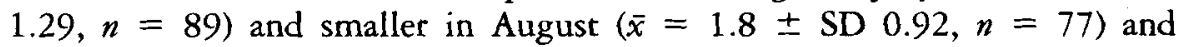
September $(\bar{x}=1.8 \pm \mathrm{SD} 1.26, n=73)$. Analysis of variance revealed no significant difference in mean pod size by month $(F(2,236)=2.52, P=$ $0.08)$ or between years $(F(1,237)=0.86, P=0.35)$.

Figure 6. Occurrence patterns for whales photographically identified 1994-1998. Shaded cells represent presence in study area, $M=$ mother with calf, and $C=$ calf of that year. 
Table 4. Pod size summary statistics.

\begin{tabular}{lcccccc}
\hline \hline Year & $\begin{array}{c}\text { Number } \\
\text { of pods }\end{array}$ & $\begin{array}{c}\text { Mean } \\
\text { pod size }\end{array}$ & $\begin{array}{c}\text { Median } \\
\text { pod size }\end{array}$ & $\begin{array}{c}\text { Mode } \\
\text { pod size }\end{array}$ & $\begin{array}{c} \pm \text { SD } \\
\text { pod size }\end{array}$ & $\begin{array}{c}\text { Range in } \\
\text { pod size }\end{array}$ \\
\hline 1995 & 23 & 2.3 & 2 & 2 & \pm 1.18 & $1-6$ \\
1997 & 114 & 1.8 & 1 & 1 & \pm 1.33 & $1-9$ \\
1998 & 125 & 2.0 & 2 & 2 & \pm 1.02 & $1-6$ \\
Overall & 262 & 2.0 & 2 & 1 & \pm 1.18 & $1-9$ \\
\hline
\end{tabular}

\section{Pods With and Witbout Calves}

Eleven calves and nine mothers were identified in 1995 and 1998 and ranked among the most frequently sighted whales. The observed crude birth rate, as calculated by dividing the total number of all whales identified (including calves) in a given year by the number of calves observed (see Clapham and Mayo 1990), ranged from $4.3 \%$ (1997) to 13.2\% (1998). Of the two mothers identified in 1995, one was sighted in four years and one in three years (Fig. 6). The two mothers identified in 1997 were sighted in one and

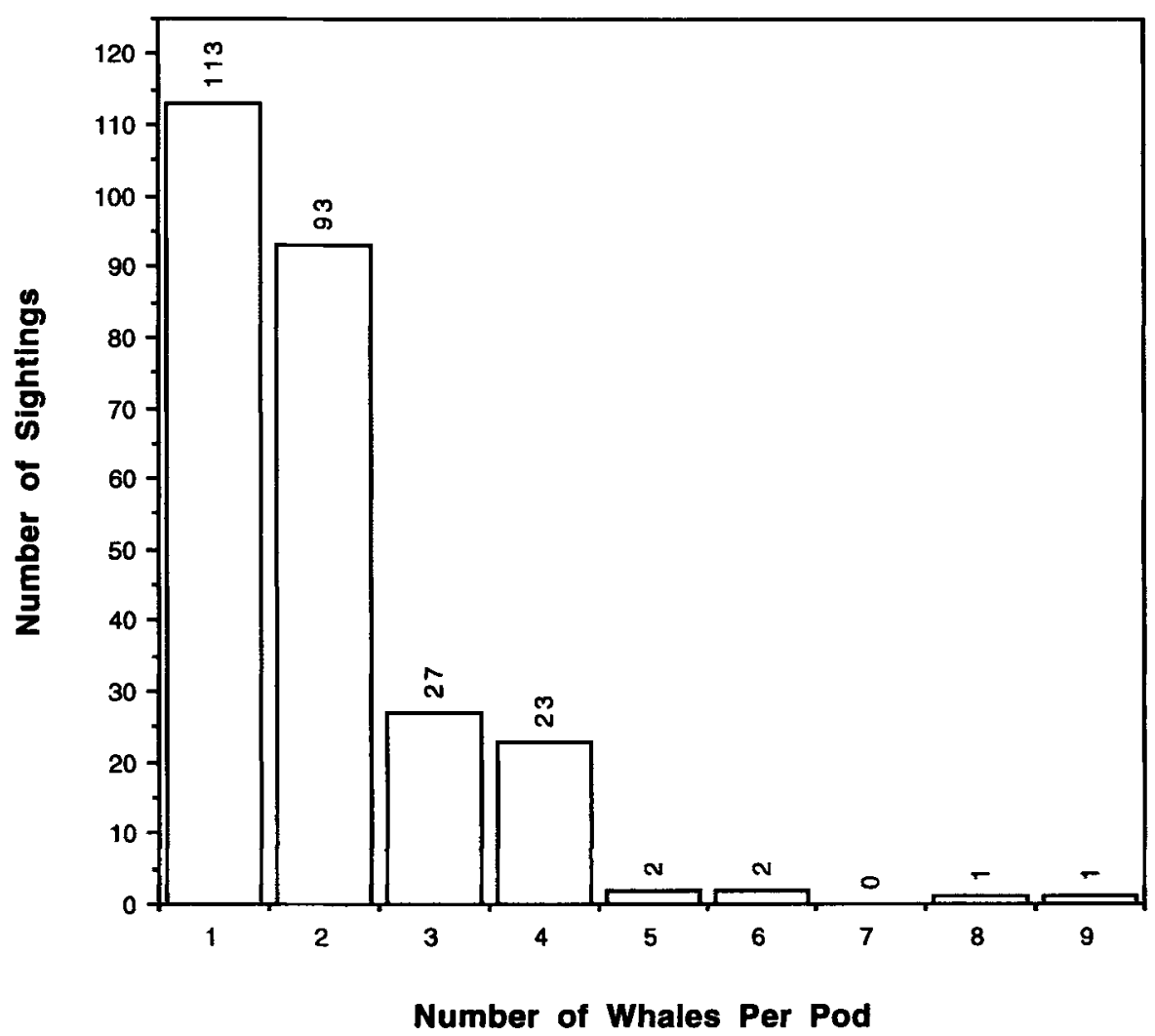

Figure 7. Frequency distribution of pod sizes between 1995 and 1998. 
three years, respectively. Finally, of the seven mothers identified in 1998, one was first sighted in that year, while $57.1 \%(n=4)$ were observed in two years and $28.6 \%(n=2)$ were sighted in each of the four years. When accompanying a calf in either 1997 or $1998,55.6 \%(n=5)$ of these mothers were sighted in all three months of that respective year, $33.3 \%(n=3)$ were observed in two months, and $11.1 \%(n=1)$ in one month (Fig. 6).

Pods containing one or more calves in 1997-1998 ranged in size from 1 to 8 whales, with a mean of $2.6 \pm$ SD $1.19(n=63)$, a median of 2 , and a mode of 2 . Pods without calves ranged in size from 1-9 whales, with a mean of $1.7 \pm \operatorname{SD} 1.09(n=176)$, a median of 1 , and a mode of 1 . The number of calves identified in each field season between 1995 and 1998 was two, two, and seven, respectively (Table 3). Only one of the four calves identified prior to the 1998 season was subsequently resighted. Seven $(77.8 \%)$ of the nine mothers identified were sighted in at least one year with a calf and one year without a calf. Five ( $71.4 \%)$ of these seven mothers had a higher number of total sightings when accompanying a calf than in years in which they had no calf. None of these mothers were sighted with a calf in sequential years. Of the two mothers identified with calves in 1995, one was subsequently sighted in 1997 with a calf and in 1998 without a calf, and one was sighted in 1997 without a calf and in 1998 with a calf. While no data were collected in 1996, these calving patterns suggest a one to two-year interbirth interval for at least some reproductive females.

Mothers and calves were closely bonded at the onset of each sampling period. However, photographic sighting records indicated that in 1997 one of the two mother-calf pairs had separated sometime between 27 August and 5 September. In 1998 mother-calf disaffiliations were observed for five of the seven pairs. Apparent calf separations occurred between the following dates in 1998: 8 July-13 August, 29 July-13 August, 29 July-18 August, 23 August-28 August, and 3 September-17 September. These dates extend from one day after the last sighting of the mother-calf pair together until the next sighting of either the mother or calf independent from one another. The earliest mother-calf separation may have occurred by 8 July-13 August, while the latest apparent separation occurred sometime between 3 and 17 September. Newly independent calves were occasionally sighted together or in the company of other still affiliated mother-calf pairs.

\section{Discussion}

During the study most whales demonstrated high levels of seasonal site fidelity and annual return to the area off the northeastern coast of Sakhalin Island, Russia. These inter- and intra-annual resighting patterns, combined with the continuous occurrence of feeding behavior, suggest that this coastal habitat plays an important role in the feeding ecology of this endangered population.

Pod sizes observed during the present study were primarily small, with most groups composed of 4 or fewer whales. These observed pod sizes closely 
correspond with those reported for eastern gray whales feeding in the Bering and Chukchi Seas (Zimushko and Ivashin 1980, Votrogov and Bogoslovskaya 1980, Bogoslovskaya et al. 1981, Würsig et al. 1986). Variables thought to influence group size include social factors, predation pressure, and prey availability (Krebs and Davies 1993). As social factors related to breeding are presumably relaxed on the feeding grounds (Würsig et al. 1986), and predation pressure does not appear to be excessive (as measured by the low number of killer whale sightings during the study), the major determinate of group size during summer feeding is probably related to foraging efficiency.

During the study period a limited number of whales $(n=69)$ were identified. The rate at which previously unidentified whales were photographed reached a pronounced asymptote early into the final year of the study. Only six previously unidentified whales (excluding seven calves) were photographed in 1998 , resulting in an overall $87.0 \%$ resighting rate. It is intriguing that the reported asymptote was reached in such a short period of time, especially given the limited number of surveys in 1994 and 1995. These findings represent a clear departure from the typical patterns reported from other largewhale studies, and suggest that the western gray whale population is perhaps smaller than previously estimated (Vladimirov 1994; Blokhin 1996; Berzin, in press), or it may be only a discrete subpopulation consistently using the northeastern Sakhalin Island feeding ground.

Gray whales in other parts of the North Pacific are suspected to sometimes segregate by age while on their feeding grounds (Zenkovich 1937, Votrogov and Bogoslovskaya 1980, Bogoslovskaya et al. 1981, Darling 1984, Darling et al. 1998). One possible explanation for the low number of individuals identified during the present study could be that only an age-specific portion of the population uses the northeastern Sakhalin coast. Age-class segregation was not, however, apparent in our observations. During the course of study we regularly documented the presence of adult reproductive females, their young of the year calves, numerous whales of apparent adult body size, and at least one known two-year-old individual.

An additional alternative explanation for the low number of whales identified during the study is that only a small portion of a larger population migrates to the northeastern Sakhalin Island coast. Small numbers of eastern gray whales have been reported to summer along the North American coast from Alaska to California, never fully migrating to more northern feeding areas (Rice and Wolman 1971). While a similar pattern may occur for the western population, aerial and ship-based surveys in the northern Okhotsk Sea reported finding concentrations of gray whales only in a small area off Piltun Lagoon (including some area outside the boundary typically covered by our research vessel during this study) (Blokhin et al. 1985; Berzin et al. 1988, 1990, 1991; Blokhin 1996; Berzin, in press). Our lack of photographic effort in other regions along the Sakhalin Island coast, and the virtual absence of data from this population's southern range off China, Korea, and Japan prohibit further speculation regarding potential subpopulation structuring. We are hopeful that a third sampling period equal in effort to 1997-1998 and 
covering a broader geographic area will be completed in 1999, allowing the first quantitative mark-recapture population estimate to be calculated (Hammond 1986, Hammond et al. 1990).

A majority of the whales identified between 1994 and 1998 displayed high rates of annual return to the study area. The annual return of whales to this region is similar to that reported for eastern gray whales off Vancouver Island (Darling 1984) and may be suggestive of foraging area philopatry as has been hypothesized for humpback whales (Megaptera novaeangliae) in the southern Gulf of Maine (Clapham et al. 1993). Annual return to the same geographic feeding area has been observed for a variety of other baleen whales (Agler $e t$ al. 1990, Dorsey et al. 1990, Sears et al. 1990, Clapham et al. 1993), and in the present case emphasizes the significance of the Piltun region as an important feeding ground for at least some portion of the western gray whale population.

Occurrence patterns of the 66 whales identified between 1997 and 1998 suggested a reasonably strong intraseasonal fidelity to the area. The mean period between first and last sighting of whales in the Piltun region was 40.6 $d$, and over one-half of the whales identified on a yearly basis were sighted in either two or three months. However, even whales demonstrating seemingly strong site fidelity were on occasion apparently absent from the region. It is difficult to determine if breaks in individual resighting patterns represent occasions when whales were in the study area but were missed photographically, or if they were indicative of movements to other regions between sightings. We suggest that whales take short excursions away from the study site, presumably related to foraging, but eventually return. Support for this idea comes from several survey days on which we sampled $20-25 \mathrm{~km}$ north and up to $10 \mathrm{~km}$ offshore of our typical search area. In each case whales found at the periphery of the study site were feeding, and all identified individuals (including one mother-calf pair) had previous and subsequent sightings within the more typical survey area.

Darling et al. (1998) characterized gray whales off Vancouver Island as having "foraging ranges" that in some cases extend over hundreds of kilometers. While existing data are insufficient to allow us to reliably assess movement parterns outside the current study area, we suggest that the unique habitat structure and infaunal prey ecology characteristic of our study site favors seasonal site fidelity as opposed to the coastal ranging behavior described by Darling et al. (1998). Our photographic resighting data showing seasonal and annual fidelity appear to support this hypothesis, as do findings from over 200 shore-based whale counts conducted between 1997 and 1998 from a 35m lighthouse near the mouth of Piltun Lagoon (Würsig et al. 1999). Theodolite-determined pod locations during these counts indicated that the highest concentrations of feeding gray whales were usually within $10 \mathrm{~km}$ of the lagoon mouth and less than $5 \mathrm{~km}$ offshore (Würsig et al. 1999). Similarly, aerial and ship-based surveys of the Okhotsk Sea found only limited numbers of gray whales away from the northeastern Sakhalin Island coast (Blokhin et al. 1985; Berzin et al. 1988, 1990, 1991; Blokhin 1996; Würsig et al. 1998; 
Berzin, in press). This apparent distributional fidelity to the coastal waters near the channel opening of Piltun Lagoon may reflect a particular biological richness of the region, perhaps related to enrichment of nearshore marine waters by tidal effluent from the lagoon. While further information regarding the benthic ecology of the region is needed, this explanation may at least partially account for the high annual return and intraseasonal site fidelity observed.

Eleven mother-calf pairs and nine mothers were identified during the study. Calves separated from their mothers between July and mid-September. Using a mean birth date of 10 January as calculated for eastern gray whales (Rice and Wolman 1971), it appears that calves off Sakhalin Island separate from their mothers at 6-8 mo. This age at separation closely corresponds with the 7-mo lactation period estimated for the species (Rice and Wolman 1971). Thus, if August is used to estimate the typical period of separation for western gray whale mother-calf pairs, January may represent the peak calving period, as is true for the eastern population (Rice and Wolman 1971).

Mother-calf pairs ranked among the most commonly sighted individuals on an intraseasonal basis, and $77.8 \%$ of these known mothers were sighted in multiple years of the study. Of the seven mothers identified in 1998, six were sighted in 1997 when they were newly pregnant. Both lactating and pregnant females are under especially high energy demands (Rice and Wolman 1971, Lockyer 1984). Therefore, it is imperative that they feed in regions capable of meeting their elevated energy requirements. The seasonal site fidelity and annual return of reproductive females reported here, combined with their need for high-quality habitat, suggests that the northeastern Sakhalin Island coast is of particular biological importance to this endangered whale population.

\section{ACKNOWLEDGMENTS}

Our sincere gratitude goes to $S$. Reeve for her participation in all aspects of this study. In the field we were fortunate to work with G. Carlash, B. Ferriss, R. LeDuc, D. Golovenkova, Y. Ivashenko, T. Kasuya, R. Pitman, I. Seryodkin, Y. Shvetsov, G. Tsidulko, E. Vorobieva, V. Vladimirov, B. Ward, and K. Zharikov. Preparations for the study were provided by A. Acevedo, S. Arms, J. Blum, S. Bräger, S. Lynn, K. Maze, M. Metro, A. Roberts, B. Walker, K. Willis, and S. Yin. Data reduction was patiently pursued by D. Allen, K. Bertalan, G. Gailey, A. Hamilton, C. Littnan, J. Oswald, G. Parra, and L. Torres. M. DeAngelis cataloged the first Piltun gray whales from 1994 and 1995. P. Clapham, one anonymous reviewer, and S. Reeve provided valuable comments on an earlier draft of this manuscript. Thanks to P. Clapham, J. Darling, D. DeMaster, T. Kasuya, S. Reilly, S. Swartz, and A. Yablokov for their excellent advice and willingness to serve as scientific advisors, and to W. Perryman for his valuable insight regarding eastern gray whales. Funding for the work in 1995 was provided by the Bureau of Oceans and International Environmental and Scientific Affairs, U.S. Department of State, International Whaling Commission, National Marine Fisheries Service, and the Humane Society of the United States. The 1997-1998 studies were funded by Sakhalin Energy Investment Company and Exxon Neftegas, and we acknowledge the assistance of N. Kralik, J. Ralston, L. Reitsema, P. Benefiel, and G. Kolesnikov. This project (1995-1998) was conducted as part of the Marine Mammal Project under Area V: Protection of Nature and the Organization of Reserves within 
the U.S.-Russia Agreement on Cooperation in the Field of Environmental Protection. This represents contribution $\# 65$ of the Marine Mammal Research Program, Texas A\&M University.

\section{Literature Cited}

Agler, B. A., J. A. Beard, R. S. Bowman, H. D. Corbett, S. E. Frohock, M. P. Hawvermale, S. K. Katona, S. S. Sadove and I. E. Seipt. 1990. Fin whale (Balaenoptera physalus) photographic identification: Methodology and preliminary results from the Western North Atlantic. Report of the International Whaling Commission (Special Issue 12):349-356.

Berzin, A. A. In press. Gray whales (Eschrichtius robustus) of the Okhotsk-Korean population in the Sea of Okhotsk. Report of the International Whaling Commission (Special Issue 17).

Berzin, A. A., V. L. Vladimirov and N. V. Doroshenko. 1988. Results of aerial surveys to study the distribution and abundance of cetaceans in the coastal waters of the Sea of Okhotsk in 1986-1987. Pages 18-25 in N. S. Chernysheva, ed. Nauchno-issledovatel'skie ra'boty po morskim mlekopitayushchim severnoi chasti Tikhogo okeana v 1986-1987. All-Union Scientific Research Institute of Fisheries and Oceanography (VNIRO), Moscow. (in Russian).

Berzin, A. A., V. L. Vladimirov and N. V. Doroshenko. 1990. Aerial surveys to determine the distribution and number of polar gray whales and beluga whales in the Sea of Okhotsk in 1985-1989. Izvestiya Tikhookeanskogo Nauchno-issledovatel'skogo Instituta Rybnogo Khozyaistva I Okeanografii (TINRO) 112:5160. (in Russian).

Berzin, A. A., V. A. Vladimirov and N. V. Doroshenko. 1991. Results of aerial surveys to study the distribution and abundance of whales in the Sea of Okhotsk in 1988-1990. Pages 6-17 in L. A. Popov, ed. Nauchno-issledovatel'skie ra'boty po morskim mlekopitayushchim severnoi chasti Tikhogo okeana v 1989-1990. All-Union Scientific Research Institute of Fisheries and Oceanography (VNIRO), Moscow. (in Russian).

Berzin, A. A., S. A. Blokhin, H. Minakuchi, R. L. Browneli, Jr., A. M. Burdin and V. N. Burkanov. 1995. Bowhead and gray whale populations in the Okhotsk Sea. Abstracts, North Pacific Marine Science Organization (PICES). Workshop on the Okhotsk Sea and adjacent areas, Vladivostok, Russia, June 19-24.

BlokHIN, S. A. 1996. Distribution, abundance and behavior of gray whales (Escbricbtius robustus) of American and Asian populations in regions of their summer location nearshore of the Far East. Izvestiya Tikhookeanskogo Nauchno-issledovatel'skogo Rybokhozyaistvennogo Tsentra 121:36-53. (in Russian).

Blokhin, S. A., M. K. Maminov and G. M. Kosygin. 1985. On the Korean-Okhotsk population of gray whales. Report of the International Whaling Commission 35: $375-376$.

Bogoslovskaya, L. S., L. M. Votgogov and T. N. Semenova. 1981. Feeding habits of the gray whale off Chukotka. Report of the International Whaling Commission 31:507-510.

Bowen, S. L. 1974. Probable extinction of the Korean stock of the gray whale (Escbrichtius robustus). Journal of Mammalogy 55:208-209.

BRownelL, R. L., JR. 1999. Okhotsk gray whales: One of the most endangered whale populations. Sphere Square 13:2-3. CETUS Newsletter, Tokyo, Japan. (in Japanese).

Browneli, R. L., JR., and C. Chun. 1977. Probable existence of the Korean stock of gray whales (Eschrichtius robustus). Journal of Mammalogy 58:237-239.

Brownell, R. L., Jr., S. A. Blokhin, A. M. Burdin, A. A. Berzin, R. G. LeDuc, R. L. Pitman and H. Minakuchi. 1997. Observations on Okhotsk-Korean gray 
whales on their feeding grounds off Sakhalin Island. Report of the International Whaling Commission 47:161-162.

Clapham, P. J. 1993. Social organization of humpback whales on a North Atlantic feeding ground. Symposium of the Zoological Society of London 66:131-145.

Clapham, P. J., and C. A. Mayo. 1990. Reproduction of humpback whales (Megaptera novaeangliae) observed in the Gulf of Maine. Report of the International Whaling Commission (Special Issue 12):171-175.

Clapham, P. J., L. S. Baraff, C. A. Carison, M. A. Christian, D. K. Mattila, C. A. Mayo, M. A. Murphy and S. Pittran. 1993. Seasonal occurrence and annual return of humpback whales, Megaptera novaeangliae, in the southern Gulf of Maine. Canadian Journal of Zoology 71:440-443.

Clapham, P. J., S. B. Young and R. L. Brownell, JR. 1999. Baleen whales: Conservation issues and the status of the most endangered populations. Mammal Review 29:35-60.

DarLING, J. 1984. Gray whales off Vancouver Island, British Columbia. Pages 267287 in M. L. Jones, S. L. Swartz, and S. Leatherwood, eds. The gray whale Eschrichtius robustus. Academic Press, Orlando, FL.

Daruing, J. D., K. E. Keogh and T. E. Steeves. 1998. Gray whale (Escbrichtius robustus) habitat utilization and prey species off Vancouver Island, B.C. Marine Mammal Science 14:692-720.

Dorsey, E. M., S. J. Stern, A. R. Hoelzel And J. Jacobsen. 1990. Minke whales (Balaenoptera acutorostrata) from the west coast of North America: Individual recognition and small-scale site fidelity. Report of the International Whaling Commission (Special Issue 12):357-368.

HAMMOND, P. S. 1986. Estimating the size of naturally marked whale populations using capture-recapture techniques. Reports of the International Whaling Commission (Special Issue 8):253-282.

Hammond, P. S., R. Sears and M. Bérubé. 1990. A note on problems in estimating the number of blue whales in the Gulf of St. Lawrence from photo-identification data. Report of the International Whaling Commission (Special Issue 12):141142.

Henderson, D. A. 1972. Men and whales at Scammon's Lagoon. Dawson's Book Shop, Los Angeles, CA.

Henderson, D. A. 1984. Nineteenth Century gray whaling: Grounds, catches, and kills, practices and depletion of the whale population. Pages 159-186 in M. L. Jones, S. L. Swartz, and S. Leatherwood eds. The gray whale Eschrichtius robustus. Academic Press, Orlando, FL.

Henderson, D. 1990. Gray whales and whalets on the China coast in 1869. Whalewatcher 24:14-16. American Cetacean Society, Los Angeles, CA.

JONEs, M. L. 1990. The reproductive cycle in gray whales based on photographic resightings of females in the breeding grounds from 1977-1982. Report of the International Whaling Commission (Special Issue 12):177-182.

Kato, H., and T. KasuYa. In press. Catch history of the Asian stock of gray whales by modern whaling with some notes on their current status and migrations. Report of the International Whaling Commission (Special Issue 17).

KREBS, J. R., AND N. B. Davies. 1993. An introduction to behavioural ecology. Blackwell Scientific Publications, London.

LOCKYER, C. 1984. Review of baleen whale reproduction and implications for management. Reports of the International Whaling Commission (Special Issue 6):2750 .

RerLu, S. B. 1992. Population biology and status of eastern Pacific gray whales: recent developments. Pages 1062-1074 in D. R. McCullough and R. H. Barrett, eds. Wildlife 2001: Populations. Elsevier Applied Science, New York, NY.

Rice, D. W., ANd A. A. Wolman. 1971. The life history and ecology of the gray whale 
(Escbrichtius robustus). American Society of Mammalogists Special Publication 3: $1-142$.

Sears, R., J. M. Wirliamson, F. W. Wenzel, M. Bérubé, D. Grendron and P. Jones. 1990. Photographic identification of the blue whale (Balaenoptera musculus) in the Gulf of St. Lawrence, Canada. Report of the International Whaling Commission (Special Issue 12):335-342.

Seipt, 1. E., P. J. Clapham, C. A. Mayo and M. P. Hawrvermale. 1990. Population characteristics of individually identified fin whales Balaenoptera physalus in Massachusetts Bay. Fishery Bulletin, U.S. 88:271-278.

Swartz, S. L. 1986. Demography, migrations, and behavior of gray whales Eschrichtius robustus (Lilljeborg, 1861) in San Ignacio Lagoon, Baja California, Sur, Mexico and in their winter range. $\mathrm{Ph} . \mathrm{D}$. dissertation, University of California, Santa Cruz, California. 85 pp.

Vladimirov, V. L. 1994. Recent distribution and abundance level of whales in Russian Far-Eastern seas. Russian Journal of Marine Biology 20:1-9.

Votrogov, L. M., and L. S. Bogoslovskaya. 1980. Gray whales off the Chukotka Peninsula. Report of the International Whaling Commission 30:435-437.

WÜRSIG, B., R. S. WeLLS AND D. A. CROLL. (1986). Behavior of gray whales summering near St. Lawrence Island, Bering Sea. Canadian Journal of Zoology 64:611-621.

Würsig, B., D. Weller AND A. BuRdiN. 1998. Gray whales summering off Sakhalin Island, Far East Russia: Summary of research activities: June-September 1998. A joint U.S.-Russian scientific investigation. Interim Contact Report to Sakhalin Energy Investment Company and Exxon Neftegas (unpublished). 19 pp. Available from Texas A\&M University, Marine Mammal Research Program, Galveston, TX 77551.

Würsig, B., D. Weller., A. Burdin, S. Blokhin, S. Reeve, A. Bradford and R. BROwNEL.L, JR. 1999. Gray whales summering off Sakhalin Island, Far East Russia: July-October 1997. A joint U.S.-Russian scientific investigation. Final Contact Report to Sakhalin Energy Investment Company and Exxon Neftegas (unpublished). 101 pp. Available from Texas A\&M University, Marine Mammal Research Program, Galveston, TX 77551.

Yablokov, A. V., and L. S. Bogoslovskaya. 1984. A review of Russian research on the biology and commercial whaling of the gray whale. Pages $465-485$ in $M$. L. Jones, S. L. Swartz and S. Leatherwood, eds. The gray whale Escbricbtius robustus. Academic Press, Orlando, FL.

ZENkovich, B. A. 1937. More on the gray California whale (Rhachianectes glaucus, Cope 1864). Vestnik Akademiya Nauk SSSR Dal'nevostochnyi Filiala 23:91-103. (in Russian).

ZimushKo, V. V., AND M. V. IVASHIN. 1980. Some results of Soviet investigations and whaling of gray whales (Eschricbtius robustus Lilljeborg, 1861). Report of the International Whaling Commission 30:237-246. 